\title{
Reinvestigation of the crystal structure and cryomagnetic behaviour of copper(II) propionates
}

\author{
Y. H. Chung, ${ }^{a}$ H. H. Wei, ${ }^{a *}$ Y. H. Liu, ${ }^{b}$ G. H Lee ${ }^{\mathrm{b}}$ and Yu Wang ${ }^{\mathrm{b}}$ \\ "Department of Chemistry, Tamkang University, Tamsui. Taiwan \\ ${ }^{\mathrm{b}}$ Instrumentation Center, College of Science, National Taiwan University, Taipei, Taiwan
}

(Received 10 April 1997; accepted 3 September 1997)

\begin{abstract}
Two different complexes of copper(II) propionates, $\left[\mathrm{Cu}_{2}\left(\mathrm{C}_{2} \mathrm{H}_{5} \mathrm{CO}_{2}\right)_{4}\right]$ (1) and $\mathrm{Na}\left[\mathrm{Cu}_{4}\right.$ $\left.\left(\mathrm{C}_{2} \mathrm{H}_{5} \mathrm{CO}_{2}\right)_{9}\left(\mathrm{H}_{2} \mathrm{O}\right)_{3}\right](2)$ have been isolated from the reaction of $\mathrm{Cu}(\mathrm{II})\left(\mathrm{NO}_{3}\right)_{2} 3 \mathrm{H}_{2} \mathrm{O}$ with propionic acid in an aqueous solution of $\mathrm{NaOH}$. X-ray structural analysis revealed that complex 1 consists of a one-dimensional chain of an apical-to-basal $\mathrm{Cu}-\mathrm{O}-\mathrm{Cu}$ linkage of pairwise binuclear anhydrous cupric propionates, which agrees with results previously reported. Compound 2 consists of a cation $\mathrm{Na}^{+}$which interacts with six oxygen atoms of carboxylate groups, and anionic $\left[\mathrm{Cu}_{4}\left(\mathrm{C}_{2} \mathrm{H}_{5} \mathrm{CO}_{2}\right)_{9}\left(\mathrm{H}_{2} \mathrm{O}\right)_{3}\right]^{-}$ion, which contains one isolated syn-syncarboxylato dimeric copper(II) complex $\left[\mathrm{Cu}_{2}\left(\mathrm{C}_{2} \mathrm{H}_{5} \mathrm{CO}_{2}\right)_{4}\left(\mathrm{H}_{2} \mathrm{O}\right)_{3}\right]$, and a linear chain containing one sin-sincarboxylato dimeric $\left[\mathrm{Cu}_{2}\left(\mathrm{C}_{2} \mathrm{H}_{5} \mathrm{CO}_{2}\right)_{4}\right]$ and its apical position linked by a carboxylate bridge with a unit of $\left[\mathrm{Cu}\left(\mathrm{C}_{2} \mathrm{H}_{5} \mathrm{CO}_{2}\right)\left(\mathrm{H}_{2} \mathrm{O}\right)\right]$. Cryomagnetic susceptibilities 1 and $\mathbf{2}$ have been measured over the temperature range $4-300 \mathrm{~K}$. In 1, the spins are coupled through an alternating one-dimensional antiferromagnetic interaction. In 2 , the cryomagnetic exchange interaction has been interpreted in terms of a strong antiferromagnetic interaction associated with the two paired dinuclear units of $\mathrm{Cu}(\mathrm{II}) \cdots \mathrm{Cu}(\mathrm{II})$, and one mononuclear $\mathrm{Cu}(\mathrm{II})$ unit which complies with a Curie-Weiss law. 1998 Elsevier Science Ltd. All rights reserved
\end{abstract}

Keywords: crystal structure; magnetic property: copper complexes; polynuclear complexes: propionate complexes.

The chemistry of the copper complexes with various carboxylates has been investigated for long time. A large number of binuclear copper(II) carboxylate adducts, $\left[\mathrm{Cu}\left(\mathrm{RCO}_{2}\right) \mathrm{L}\right]_{2}$, have extensively been investigated in an effort to clarify the factors influencing the magnitude of the intramolecular magnetic exchange interaction which occurs between two $\mathrm{Cu}(\mathrm{II})$ ions in these compounds [1-7]. In most $\left[\mathrm{Cu}\left(\mathrm{RCO}_{2}\right)_{2} \mathrm{~L}\right]_{2}$ complexes, two copper(II) atoms are bridged in pairs by four syn-syn-carboxylato groups with two additional unidentate ligand (L) occupying the apical position.

Relatively few studies have been reported on the magneto-structural corrections in the non-adduct complex of copper(II) carboxylates such as $\left[\mathrm{Cu}_{2}\left(\mathrm{RCO}_{2}\right)_{4}\right]$ [4]. Although an X-ray crystallographic structure [8] and cryomagnetic data [9] of the dimeric

* Author to whom correspondence should be addressed.
copper(II) propionate $\left[\mathrm{Cu}_{2}\left(\mathrm{C}_{2} \mathrm{H}_{5} \mathrm{CO}_{2}\right)_{4}\right]$ have been reported in the past, the precise cryomagnetic behaviour, especially with regard to the X-ray structural data for this compound has, however, been rather controversial.

The contrasting structures of dimeric adduct $\left[\mathrm{Cu}_{2}\left(\mathrm{RCO}_{2}\right)_{4} \mathrm{~L}_{2}\right]$, and polymeric non-adduct $\left[\mathrm{Cu}_{2}\left(\mathrm{RCO}_{2}\right)_{4}\right]$ prompted us to reinvestigate in particular the cryomagnetic behaviour of the non-adduct copper(II) propionate $\left[\mathrm{Cu}_{2}\left(\mathrm{C}_{2} \mathrm{H}_{5} \mathrm{CO}_{2}\right)_{4}\right]$ compound. However, in the course of our synthetic investigations of the copper(II) propionic acid system, the products of a blue-green complex $\left[\mathrm{Cu}_{2}\left(\mathrm{C}_{2} \mathrm{H}_{5} \mathrm{CO}_{2}\right)_{4}\right]$ (1) and an emerald-green species $\mathrm{Na}\left[\mathrm{Cu}_{4}\left(\mathrm{C}_{2} \mathrm{H}_{5} \mathrm{CO}_{2}\right)_{9}\left(\mathrm{H}_{2} \mathrm{O}\right)_{3}\right]$ (2) are isolated from the mixted aqueous solution of $\mathrm{Cu}\left(\mathrm{NO}_{3}\right)_{2} \cdot 3 \mathrm{H}_{2} \mathrm{O}$, propionic acid, and $\mathrm{NaOH}$ depending on their isolation conditions. The preparation, structure, EPR, and cryomagnetic behaviours of these two compounds are described in this paper. 


\section{EXPERIMENTAL}

Preparation of $\left[\mathrm{Cu}_{2}\left(\mathrm{C}_{2} \mathrm{H}_{5} \mathrm{CO}_{2}\right)_{4}\right]$ (1) and $\mathrm{Na}\left[\mathrm{Cu}_{4}\right.$
$\left.\left(\mathrm{C}_{2} \mathrm{H}_{5} \mathrm{CO}_{2}\right)_{9}\left(\mathrm{H}_{2} \mathrm{O}\right)_{3}\right](2)$

In the earliest report [9], unhydrated copper(II) propionate was prepared from excess of the diluted acid and copper carbonate and then dehydrated at $100^{\circ} \mathrm{C}$ over posphoric oxide. Here we modified the procedure as following : propionic acid $(10 \mathrm{mmol})$ was dissolved in $50 \mathrm{~cm}^{3}$ of water, and the resulting solution was adjusted to $\mathrm{pH}=5.8$ with ca $100 \mathrm{~cm}^{3}$ of $0.25 \mathrm{M}$ $\mathrm{NaOH}$. To this solution $25 \mathrm{~cm}^{3}$ of aqueous $\mathrm{Cu}\left(\mathrm{NO}_{3}\right)_{2} \cdot 3 \mathrm{H}_{2} \mathrm{O}(60 \mathrm{mmol})$ was added under stirring. The resulting blue-green solution was allowed to stand in air at room temperature for one week and the earlier blue-green crystals of the compound $\mathbf{1}$ were filtered, after which the filtrate was concentrated (ca 3 weeks) to one third of its volume and the emerald-green crystals suitable for X-ray analysis of compound $\mathbf{2}$ were collected, washed with water, and air-dried at room temperature. Anal. Calc. (found) for $\mathrm{C}_{12} \mathrm{H}_{20} \mathrm{Cu}_{2} \mathrm{O}_{8}(\mathbf{1})$ : C, $33.40(33.48) \mathrm{H}, 4.60(4.62) \%$. IR( $\left(\mathrm{cm}^{-1}\right): 1628(\mathrm{~s})$, 1590,1556 (s). Calc. (found) for $\mathrm{C}_{27} \mathrm{H}_{51} \mathrm{Cu}_{4} \mathrm{NaO}_{21}$ (2): C, 32.77 (32.56); H, $5.16(5.21) \%$. IR $\left(\mathrm{cm}^{-1}\right): 1619$ (s), 1592 (s), 1540.

\section{$X$-ray crystallography}

Intensities and lattice parameters of the blue-green crystal of 1 and the emerald-green crystal of $\mathbf{2}$ were measured at $25^{\circ} \mathrm{C}$ on an Enraf-Nonius CAD4 diffractometer by using monochromated Mo $-K_{\alpha}$ radiation. Crystal parameters and the selected data of collection and refinements of the complexes are summarized in Table 1. The structure was solved by heavyatom method and subsequent difference Fourier maps, followed by full-matrix least-squares refinement based on $F$ with the NRCVAX computer program [10]. The hydrogen atoms were placed at calculated positions with isotropic thermal parameters.

\section{Physical measurements}

Infrared spectra were recorded on a Bio-Rad FTS40FTIR spectrophotometer as $\mathrm{KBr}$ pellets in the $4000400 \mathrm{~cm}^{-1}$ region. X-band EPR spectra at $300 \mathrm{~K}$ for the complexes were recorded on a Bruker ECS-106 spectrometer. Temperature dependence of magnetic susceptibilities of the polycrystalline sample were measured between 4.2 and $300 \mathrm{~K}$ at a field of $1 T$ using a Quantum Design Model MPMS computer-controlled SQUID magnetometer. Diamagnetic corrections were made using Pascal's constants [11].

\section{RESULTS AND DISCUSSION}

\section{Synthesis and structural characterizations of $\mathbf{1}$ and $\mathbf{2}$}

The reaction of $\mathrm{Cu}\left(\mathrm{NO}_{3}\right)_{2} \cdot 3 \mathrm{H}_{2} \mathrm{O}$ and $\mathrm{NaOH}$ with propionic acid in aqueous solution, on the time of

Table 1. Crystallographic data for compounds $\mathbf{1}$ and $\mathbf{2}$

\begin{tabular}{lll}
\hline & 1 & 2 \\
\hline Formula & $\mathrm{C}_{12} \mathrm{H}_{20} \mathrm{Cu}_{2} \mathrm{O}_{8}$ & $\mathrm{C}_{27} \mathrm{H}_{51} \mathrm{Cu}_{4} \mathrm{NaO}_{21}$ \\
Formula weight & 419.37 & 988.85 \\
Size, mm & $0.05 \times 0.13 \times 0.40$ & $0.40 \times 0.50 \times 0.50$ \\
$T(\mathrm{~K})$ & 298 & 298 \\
Crystal system & Triclinic & Monoclinic \\
Space group & $P \overline{1}$ & $P 2, / n$ \\
$a,(\AA)$ & $5.1846(19)$ & $13.470(6)$ \\
$b,(\AA)$ & $8.4373(16)$ & $26.370(14)$ \\
$c,(\AA)$ & $9.523(3)$ & $13.540(6)$ \\
$\alpha,\left(^{\circ}\right)$ & $91.732(20)$ & \\
$\beta,\left({ }^{\circ}\right)$ & $91.79(3)$ & $114.06440(0)$ \\
$\gamma,\left(^{\circ}\right)$ & $105.06(3)$ & \\
$V, \AA^{3}$ & $401.76(21)$ & $4391(3)$ \\
$Z$ & 1 & 4 \\
$D_{c}, \mathrm{gcm}^{-3}$ & 1.73 & 1.496 \\
$F(000)$ & 215 & 2038 \\
$\lambda\left[\mathrm{Mo}^{-3} K_{\alpha}\right], \AA$ & 0.7107 & 0.7107 \\
$\mu, \mathrm{mm}^{-1}$ & 26.875 & 19.789 \\
$N$ & 1415 & 6019 \\
$N_{\mathrm{o}}(I>2 \sigma(I))$ & 1235 & 3942 \\
$R^{a}$ & 0.024 & 0.046 \\
$R_{w}{ }^{b}$ & 0.023 & 0.050 \\
\hline
\end{tabular}

${ }^{a} R=\Sigma\left|F_{\mathrm{o}}-\mathrm{F}_{\mathrm{c}}\right| / \Sigma\left|F_{\mathrm{o}}\right|,{ }^{b} R_{w}=\left[\Sigma w^{2}\left(\left|F_{\mathrm{o}}-F_{\mathrm{c}}\right|^{2} / \Sigma w^{2}\left|F_{\mathrm{o}}\right|^{2}\right]^{1 / 2}\right.$ 
crystal growing, deposited the initial product bluegreen crystal 1 from the mixed solution, and then deposited the emerald-green compound 2 after concentration of the solution.

The crystal structure of 1 is in good agreement with that previously reported [8] which shows the structure of the polymeric chain of $\left[\mathrm{Cu}_{2}\left(\mathrm{C}_{2} \mathrm{H}_{5} \mathrm{CO}_{2}\right)_{4}\right]$ (as shown in Fig. 1). The $s y n-s y n$ propionate bridged $\mathrm{Cu}(\mathrm{II})$ dimer is self-assembly oxygen-bridged (apical) to the nearest dimers. This bridging arrangement gives rise to a $\mathrm{Cu} \cdot \mathrm{Cu}^{\prime}$ (apical) distance of $3.2442(3) \AA$, substantially longer than $\mathrm{Cu} \cdots \mathrm{Cu}$ of $2.5826(12) \AA$ associated with the $\mathrm{Cu}_{2}\left(\mathrm{C}_{2} \mathrm{H}_{5} \mathrm{CO}_{2}\right)_{4}$ core. There was no doubt that the original $\mathrm{Cu} \cdots \mathrm{Cu}$ distances of $2.578(4) \AA[8]$ are not significantly different from our refinement (2.5826(12) $\AA$ ). The original $\mathrm{Cu}-\mathrm{O}$ (basal) distance of $1.94 \AA$ is shown to be somewhat shorter than the 2.0024(19) $\AA$ from our refinement, whereas the present $\mathrm{Cu}-\mathrm{O}$ (apical) distance of 2.2259(19) $\AA$ is somewhat shorter at 2.28 (1) $\AA$ in the original structure. The most important part of the previous determination was the geometry of their bridging propionate groups, the mean $\mathrm{O}-\mathrm{C}-\mathrm{O}$ angle (113 $)$ was clearly quite different from our refinement value of 124.2 .

The crystal structure of $\mathbf{2}$ is shown in Fig. 2. Representative bond distances and angles are compiled in Table 2. The structure is composed of three units of formula $\mathrm{Na}\left[\mathrm{Cu}_{4}\left(\mathrm{C}_{2} \mathrm{H}_{5} \mathrm{CO}_{2}\right)_{9}\left(\mathrm{H}_{2} \mathrm{O}\right)_{3}\right]$ (2); (i) the discrete hydrated binuclear $\left[\mathrm{Cu}_{2}\left(\mathrm{C}_{2} \mathrm{H}_{5} \mathrm{CO}_{2}\right)_{4}\left(\mathrm{H}_{2} \mathrm{O}\right)_{2}\right](\mathrm{a})$, where two $\mathrm{Cu}(\mathrm{II})$ atoms are bridged by four propionate groups in $s y n-s y n$ conformation; (ii) The bridged $\mathrm{Cu}(1) \cdots \mathrm{Cu}(2)$ distance, $2.5777(16) \AA$, which is close to that of 1 or to that of the well-known copper(II) acetate monhydrate dimer [12] and (iii) the polymeric chain of $\left[\mathrm{Cu}_{4}\left(\mathrm{C}_{2} \mathrm{H}_{5} \mathrm{CO}_{2}\right)_{5}\left(\mathrm{H}_{2} \mathrm{O}\right)\right]$ moiety, which consists of one unhydrated copper(II) propionate $\left[\mathrm{Cu}_{2}\left(\mathrm{C}_{2} \mathrm{H}_{5} \mathrm{CO}_{2}\right)_{4}\right]$ dimer $(\mathbf{b})$, and its apical positions which are bridged by two additional syn-antipropionate groups $[\mathrm{O}(15)-\mathrm{C}(19)-\mathrm{O}(16)]$ from the axial position of the central copper(II) [Cu $\left.\left(\mathrm{C}_{2} \mathrm{H}_{5} \mathrm{CO}_{2}\right)_{2}\left(\mathrm{H}_{2} \mathrm{O}\right)\right]$ (c) moiety. In $\mathrm{c}$, the $\mathrm{Cu}(4)$ atom is coordinated by one oxygen atom $[\mathrm{O}(16)]$ from the bridged syn anti-propionate group, two oxygen atoms of $O(17)$ and $O(19)$ from monodentate propionate groups, one oxygen atom $O(21)$ from an aqua ligand, and one oxygen atom $O(19)$ from the neighbour $c$ moiety, thus forming a distorted square pyramidal structure. In addition, the oxygen $O(19)$ is selfassembling and bridged to the next $\mathrm{Cu}(4)$ of the neighbour $\mathrm{c}$ unit. These bridged $\mathrm{Cu} \cdots \mathrm{Cu}$ distances for $\mathrm{Cu}(1) \cdots \mathrm{Cu}(2), \mathrm{Cu}(3) \cdots \mathrm{Cu}(3)$, and $\mathrm{Cu}(4) \cdots \mathrm{Cu}(4)$ in $\mathbf{a}, \mathbf{b}$, and $\mathbf{c}$ moieties are 2.5777(6), 2.6092(20), and $3.2146(20) \AA$, respectively.

Finally, it is noteworthy that $\mathrm{Na}^{+}$cation is sixcoordinated with six oxygen atoms $[\mathrm{O}(2), \mathrm{O}(9), \mathrm{O}(13)$, $\mathrm{O}(15), \mathrm{O}(18)$, and $\mathrm{O}(20)]$ of the subunits of $\mathbf{a}, \mathbf{b}$, and c, respectively, as shown in Fig. 2. The mean $\mathrm{Na}-\mathrm{O}$ interatomic distance is $2.40 \AA$.

\section{Magnetic properties}

The room-temperature X-band (9.8 GHz) EPR spectra of the samples of 1 and 2 show a broad signal

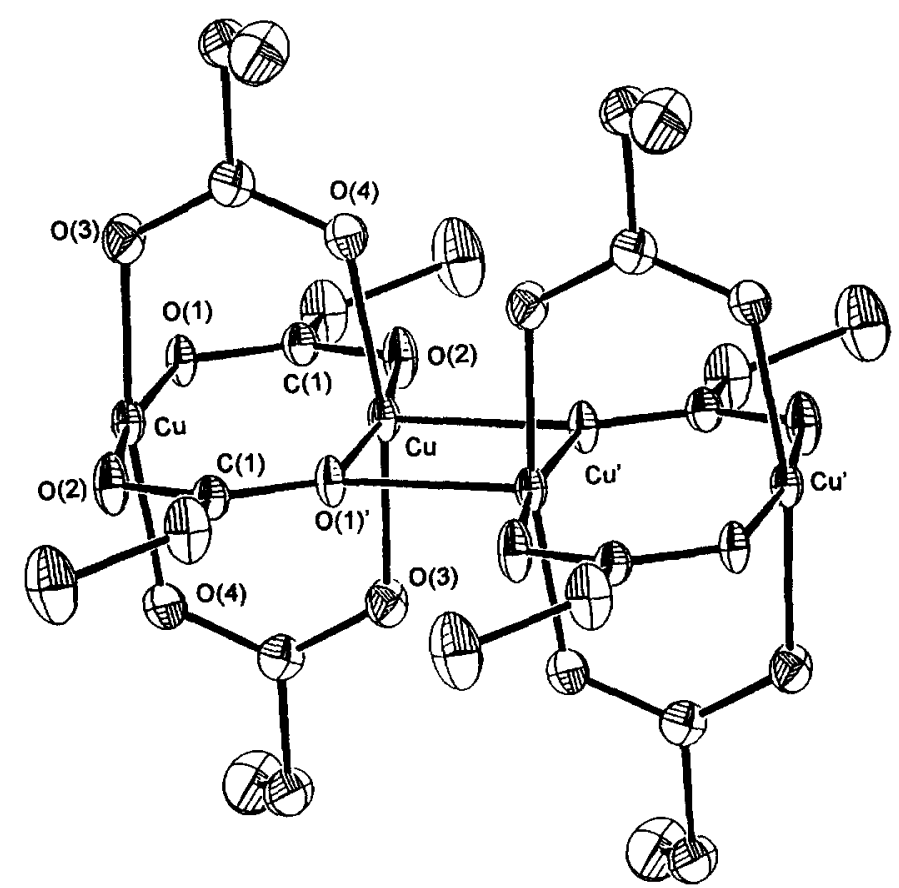

Fig. 1. ORTEP stereoview of 1 (30\% probability thermal ellipsoids). 


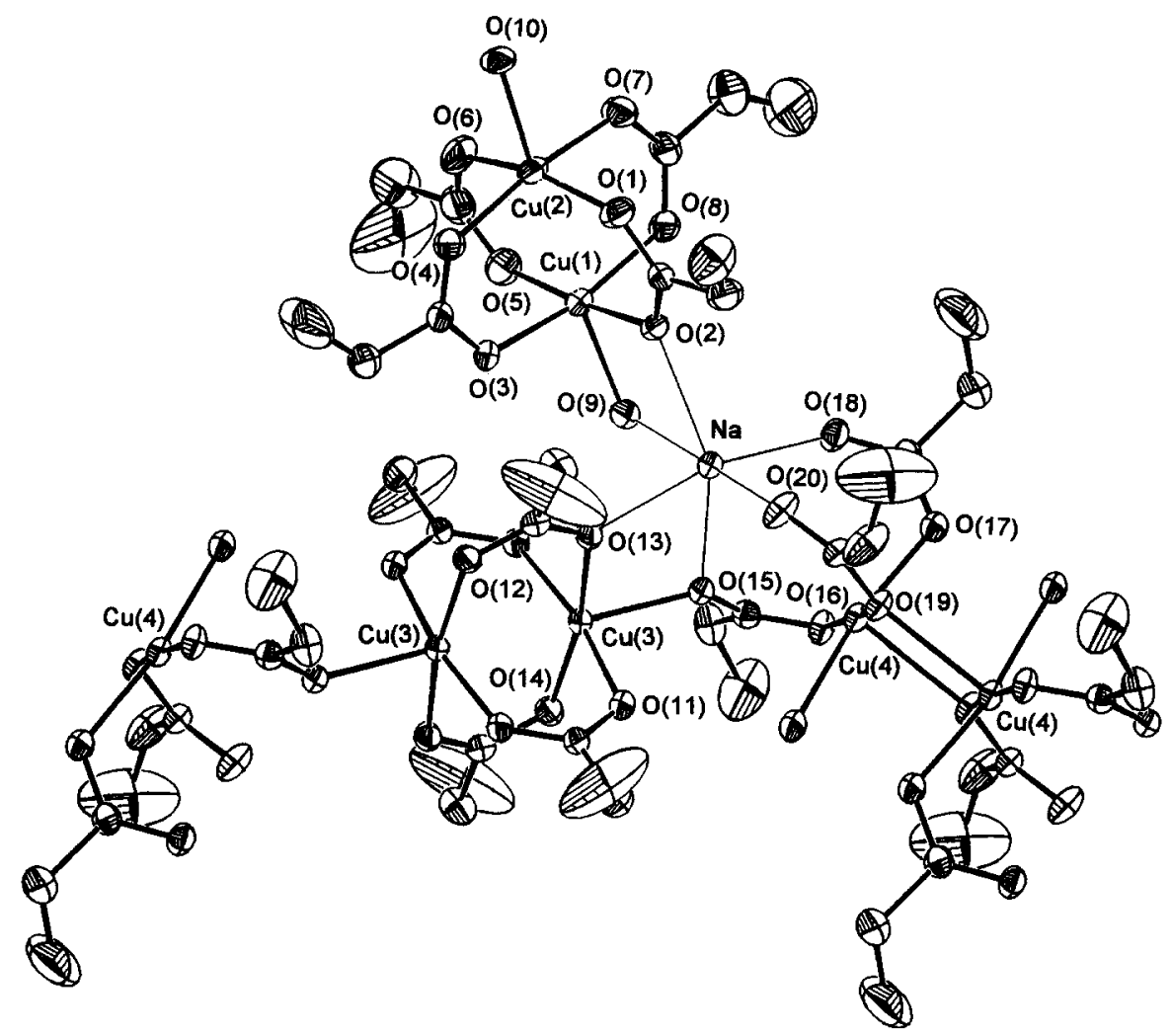

Fig. 2. ORTEP stereoview of 2 ( $30 \%$ probability thermal ellipsoids).

with a pronounced hump at $g=2.07$ for 1 and 2.05 for 2 respectively. The results of the temperature dependence of magnetic measurements for $\left[\mathrm{Cu}_{2}\left(\mathrm{C}_{2} \mathrm{H}_{5} \mathrm{CO}_{2}\right)_{4}\right] 1$ and $\mathrm{Na}\left[\mathrm{Cu}_{4}\left(\mathrm{C}_{2} \mathrm{H}_{5} \mathrm{CO}_{2}\right)_{9}\left(\mathrm{H}_{2} \mathrm{O}\right)_{3}\right] 2$ are illustrated in Figs 3 and 4, respectively.

The solid lines in Fig. 3 of compound 1 represent a best fit of data. As already mentioned in the molecular structure section, the bond distance of the two copper(II) ions $\mathrm{Cu} \cdots \mathrm{Cu}$ (basal) is shorter than that of the self-assembly oxygen-bridged $\mathrm{Cu}^{\prime} \cdot \mathrm{Cu}^{\prime}$ (apical) in this polymeric chain. Thus there are two magnetic interactions present in the system. Consequently, the data were analyse by use of an analytical expression for the exchange interaction in an alternating chain of $S=1 / 2$ ions developed by Hatifield $[13,14]$ which has the following form:

$$
\chi_{\mathrm{m}}=N g^{2} \mu_{\mathrm{B}}^{2}\left[\left(A+B_{x}+C_{x}^{2}\right) /\left(1+D_{x}+E_{x}^{2}+F_{x}^{3}\right)\right]
$$

with $x=J / k T$. The coefficients $A-F$ are functions of the alternation parameter $\alpha$ defined by the Hamiltonian

$$
H=-2 J \sum_{i=1}^{n / 2}\left[S_{2 i} S_{2 i-1}+\alpha S_{2 i} S_{2 i+1}\right]
$$

where $J$ and $\alpha J$ are the coupling constants of $\mathrm{Cu} \cdots \mathrm{Cu}$ and $\mathrm{Cu} \cdots \mathrm{Cu}^{\prime}$ respectively. The data fit of this expression resulted (the solid lines in Fig. 3) in
$J=-220 \mathrm{~cm}^{-1}, g=2.07$ (from EPR) and the alternation parameter $\alpha=0.10$. It is noteworthy that the original reported $2 J$ value of $300 \mathrm{~cm}^{-1}$ for compound 1 [9], obtained from the simple Bleaney-Bowers equation of a two spin system with $H=2 J S_{1} S_{2}$, is smaller than that of $2 J$ obtained by us.

The cryomagnetic susceptibility of compound $\mathbf{2}$ is illustrated in Fig. 4, in the form of $\chi_{m}(4 \mathrm{Cu})$ and $\chi_{m} T$ vs $T$ plots. Upon lowering the temperature from 300 $\mathrm{K}$ to about $90 \mathrm{~K}$, the $\chi_{\mathrm{m}} T$ value decreases from 0.86 $\mathrm{cm}^{3} \mathrm{~mol}^{-1} \mathrm{~K}\left(\mu_{\mathrm{eff}}=2.61 \mu_{\mathrm{B}}\right)$ to a value of $0.39 \mathrm{~cm}^{3}$ $\mathrm{mol}^{-1} \mathrm{~K}\left(\mu_{\mathrm{eff}}=1.75 \mu_{\mathrm{B}}\right)$ indicating a strong antiferromagnetic interaction, whereas on reaching an extended plateau between 90 and $8 \mathrm{~K}$, the values of $\chi_{\mathrm{m}} T$ remain practically constant, and finally decreases below $8 \mathrm{~K}$. In view of the crystal structure of 2 , magneto-structural correlation is complicated in the present system, nevertheless, the shorter distance between copper(II) atoms with bridging a $s y n-s y n$ carboxylate dimer, the exchange coupling is always larger and antiferromagnetic in nature [4]. Clearly, as mentioned above in the structural analysis, this strong antiferromagnetic interaction should occur between $\mathrm{Cu}(1) \cdots \mathrm{Cu}(2)$ and $\mathrm{Cu}(3) \cdots \mathrm{Cu}(3)$. The magnetic interaction between the self-assembly oxygen-bridged $\mathrm{Cu}(4) \cdots \mathrm{Cu}(4)$ is also rather smaller in compound 1. These become virtually diamagnetic at low temperature and $\mathrm{Cu}(4)$ dominates the magnetic response 
Table 2. Selected bond distances $(\AA)$ and bond angles ( ) of 1 and 2

\begin{tabular}{|c|c|c|c|c|}
\hline \multicolumn{5}{|l|}{ Compound 1} \\
\hline $\mathrm{Cu}-\mathrm{Cu}$ & $2.5826(12)$ & \multicolumn{3}{|l|}{$3.2442(13)$} \\
\hline $\mathrm{Cu}-\mathrm{O}(1)$ & $2.0024(19)$ & $\mathrm{Cu}-\mathrm{O}(2)$ & \multicolumn{2}{|c|}{$\begin{array}{l}3.2442(13) \\
1.9632(20)\end{array}$} \\
\hline $\mathrm{Cu}-\mathrm{O}(3)$ & $1.9378(21)$ & \\
\hline $\mathrm{Cu}-\mathrm{O}(1)^{\prime}$ & $2.2259(19)$ & & & \\
\hline $\mathrm{O}(1)-\mathrm{Cu}-\mathrm{O}(2)$ & $169.56(7)$ & $\mathrm{O}(3)-\mathrm{Cu}-\mathrm{O}(4)$ & \multicolumn{2}{|c|}{$169.69(8)$} \\
\hline $\mathrm{Cu}-\mathrm{O}(1)-\mathrm{Cu}^{\prime}$ & $100.08(8)$ & $O(1)-C(1)-O(2)$ & \multicolumn{2}{|c|}{$123.5(3)$} \\
\hline$O(3)-C(4)-O(4)$ & $124.9(3)$ & $\mathrm{Cu}-\mathrm{O}(2)-\mathrm{C}(1)$ & \multicolumn{2}{|c|}{$122.40(18)$} \\
\hline $\mathrm{Cu}(-\mathrm{O}(1)-\mathrm{C}(1)$ & $124.41(17)$ & $\mathrm{Cu}^{\prime}-\mathrm{O}(1)-\mathrm{C}(1)$ & \multicolumn{2}{|c|}{$135.31(17)$} \\
\hline \multicolumn{5}{|l|}{ Compound 2} \\
\hline $\mathrm{Cu}(1)-\mathrm{Cu}(2)$ & $2.5777(16)$ & $\mathrm{Cu}(3)-\mathrm{Cu}(3)$ & \multicolumn{2}{|c|}{$2.6092(20)$} \\
\hline $\mathrm{Cu}(4)-\mathrm{Cu}(4)$ & $3.2146(20)$ & $\mathrm{Cu}(1)-\mathrm{O}(2)$ & $1.953(5$ & \\
\hline $\mathrm{Cu}(1)-\mathrm{O}(3)$ & $1.958(5)$ & $\mathrm{Cu}(1)-\mathrm{O}(5)$ & $1.929(6$ & \\
\hline $\mathrm{Cu}(1)-\mathrm{O}(9)$ & $2.175(5)$ & $\mathrm{Cu}(2)-\mathrm{O}(4)$ & $1.947(6$ & \\
\hline $\mathrm{Cu}(2)-\mathrm{O}(6)$ & $1.982(7)$ & $\mathrm{Cu}(2)-\mathrm{O}(7)$ & $1.932(6$ & \\
\hline $\mathrm{Cu}(2)-\mathrm{O}(10)$ & $2.102(6)$ & $\mathrm{Cu}(3)-\mathrm{O}(11)$ & $1.989(5$ & \\
\hline $\mathrm{Cu}(3)-\mathrm{O}(12)$ & $1.987(5)$ & $\mathrm{Cu}(3)-\mathrm{O}(13)$ & $1.968(5$ & \\
\hline $\mathrm{Cu}(3)-\mathrm{O}(15)$ & $2.120(5)$ & $\mathrm{Cu}(4)-\mathrm{O}(16)$ & $1.934(5$ & \\
\hline $\mathrm{Cu}(4)-\mathrm{O}(17)$ & $1.969(5)$ & $\mathrm{Cu}(4)-\mathrm{O}(19)$ & $1.943(5$ & \\
\hline $\mathrm{Cu}(4)-\mathrm{O}(19)$ & $2.299(5)$ & $\mathrm{Cu}(4)-\mathrm{O}(21)$ & $2.043(6$ & \\
\hline $\mathrm{Na}-\mathrm{O}(2)$ & $2.420(6)$ & $\mathrm{Na}-\mathrm{O}(9)$ & $2.591(7$ & \\
\hline $\mathrm{Na}-\mathrm{O}(13)$ & $2.387(6)$ & $\mathrm{Na}-\mathrm{O}(15)$ & $2.428(6$ & \\
\hline $\mathrm{Na}-\mathrm{O}(18)$ & $2.301((6)$ & $\mathrm{Na}-\mathrm{O}(20)$ & $2.294(6$ & \\
\hline $\mathrm{O}(3)-\mathrm{Cu}(1)-\mathrm{O}(8)$ & $167.39(23)$ & $\mathrm{O}(2)-\mathrm{Cu}(1)$ & $O(5)$ & $174.0(3)$ \\
\hline $\mathrm{O}(2)-\mathrm{Cu}(1)-\mathrm{O}(9)$ & $87.90(22)$ & $\mathrm{O}(5)-\mathrm{Cu}(1)$ & $O(9)$ & $98.0(3)$ \\
\hline $\mathrm{O}(3)-\mathrm{Cu}(1)-\mathrm{O}(9)$ & $96.02(22)$ & $\mathrm{O}(1)-\mathrm{Cu}(2)$ & $O(6)$ & $164.6(3)$ \\
\hline $\mathrm{O}(1)-\mathrm{Cu}(2)-\mathrm{O}(4)$ & $91.5(3)$ & $\mathrm{O}(4)-\mathrm{Cu}(2)$ & $O(7)$ & $171.0(3)$ \\
\hline $\mathrm{O}(1)-\mathrm{C}(1)-\mathrm{O}(2)$ & $124.3(7)$ & $\mathrm{O}(3)-\mathrm{C}(4)-$ & $(4)$ & $125.5(8)$ \\
\hline$O(5)-C(7)-O(6)$ & $125.4(9)$ & $\mathrm{O}(7)-\mathrm{C}(10)$ & $O(8)$ & $125.2(8)$ \\
\hline $\mathrm{O}(11)-\mathrm{Cu}(3)-\mathrm{O}(12)$ & $168.85(21)$ & $\mathrm{O}(13)-\mathrm{Cu}(3$ & $-\mathrm{O}(14)$ & $168.77(21$ \\
\hline$O(11)-C(13)-O(12)$ & $124.4(7)$ & $\mathrm{O}(13)-\mathrm{C}(16$ & $-O(14)$ & $125.1(7)$ \\
\hline $\mathrm{Cu}(3)-\mathrm{O}(15)-\mathrm{C}(19)$ & $134.4(5)$ & $\mathrm{O}(15)-\mathrm{C}(19$ & $-O(16)$ & $122.4(7)$ \\
\hline $\mathrm{Cu}(4)-\mathrm{O}(16)-\mathrm{C}(19)$ & $112.3(5)$ & $\mathrm{Cu}(4)-\mathrm{O}(19$ & $-\mathrm{Cu}(4)$ & $98.29(19)$ \\
\hline $\mathrm{O}(17)-\mathrm{Cu}(4)-\mathrm{O}(21)$ & $169.85(21)$ & $\mathrm{O}(17)-\mathrm{C}(22$ & $-O(18)$ & $125.1(7)$ \\
\hline
\end{tabular}

of the compound 2. Accordingly, we attempted to fit the cryomagnetic data, however, an appropriate known theoretical model is not available, and after we tested a variety of models, the only one that gave a reasonable data fit involved two different dinuclear centres and one mononuclear centre in equal proportions, with different exchange constants. The magnetic susceptibility can be described by eqn (3),

$$
\chi_{m}=\chi_{1}+(1 / 2) \chi_{2}+\chi_{3}+N \alpha
$$

where $\chi_{1}, \chi_{2}$, and $\chi_{3}$ are the temperature-dependent magnetic susceptibilities for the units of $\mathrm{Cu}(1) \cdots \mathrm{Cu}(2), \mathrm{Cu}(3) \cdots \mathrm{Cu}(3)$, and $\mathrm{Cu}(4)$ respectively, and $N \alpha$ is the temperature-independent susceptibility. Assuming that the $\mathrm{Cu}(4)$ unit conforms to the Curie-Weiss law, with Weiss constant $\theta$ as an intermolecular exchange interaction, then $\chi_{3}=C /(T-\theta)$. The sum of the exchange Hamiltonian of $\chi_{1}$ and $\chi_{2}$ is $H=-2 J_{1} \Sigma S_{1} S_{2}-2 J_{2} \Sigma S_{1} S_{2}$ where
$S_{1}=S_{2}=1 / 2$, has the Bleaney-Bowers expression (4) [15]

$$
\begin{gathered}
\chi_{1}+(1 / 2) \chi_{2}=\left(2 N g^{2} \mu_{\mathrm{B}}^{2} / k T\right)\left\{\left[3+\exp \left(-2 J_{1} / k T\right)\right]^{-1}\right. \\
\left.+1 / 2\left[3+\exp \left(-2 J_{2} / k T\right)\right]^{-1}\right\}
\end{gathered}
$$

where $J_{1}$ and $J_{2}$ are the exchange interaction constants associated with $\mathrm{Cu}(1) \cdots \mathrm{Cu}(2)$ and $\mathrm{Cu}(3) \cdots \mathrm{Cu}(3)$ units respectively. With expression (3), and letting $J_{1}>J_{2}[2-4]$, the best fit for 2 resulted in $J_{1}=-225$ $\mathrm{cm}^{-1}, J_{2}=-160 \mathrm{~cm}^{-1}, g=2.0, C=0.39 \mathrm{~cm}^{3} \mathrm{~mol}^{-1}$ $\mathrm{K}, \theta=-0.49 \mathrm{~K}$, and $N \alpha=60 \times 10^{-6} \mathrm{~cm}^{3} \mathrm{~mol}^{-1}$. The solid line in Fig. 4 is calculated using the parameters derived above. The constant $C$ value of $0.39 \mathrm{~cm}^{3} \mathrm{~mol}^{-1}$ $\mathrm{K}$ is close to the value of $0.38 \mathrm{~cm}^{3} \mathrm{~mol}^{-1} \mathrm{~K}$ for the noncoupled one spin $S=1 / 2$ system; and the smaller $\theta$ value of $-0.49 \mathrm{~K}$ indicates that a weak intermolecular antiferromagnetic interaction contributes to the bulk susceptibility at low temperature. 


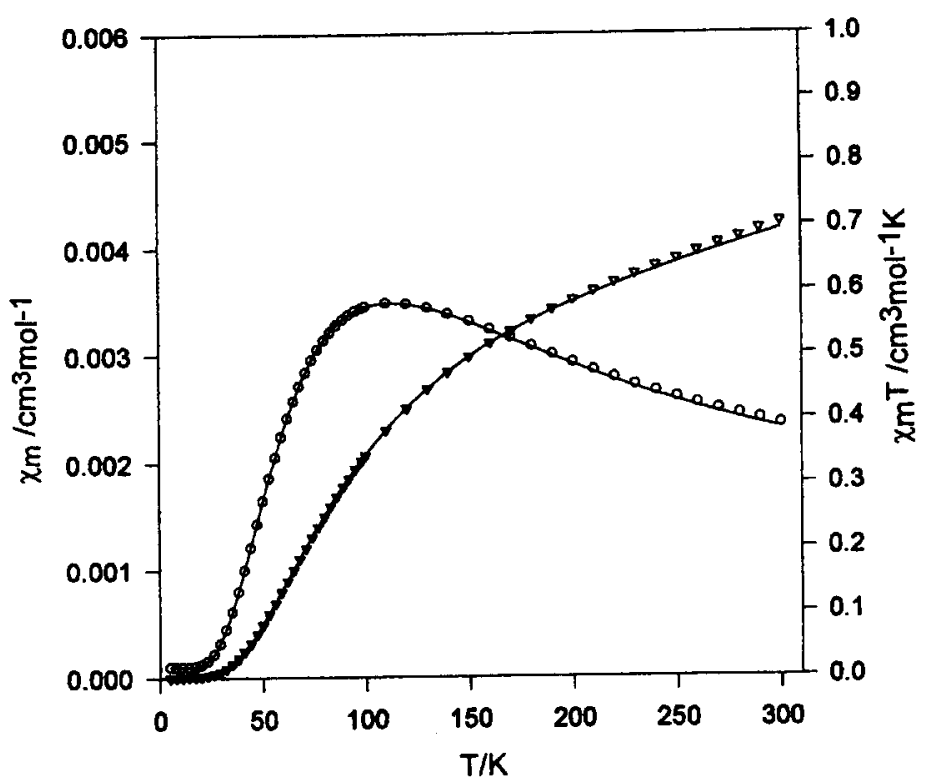

Fig. 3. Thermal variation of the molar magnetic susceptibility for 1 in the form $\chi_{\mathrm{m}}$ and $\chi_{\mathrm{m}} T$ vs $T$, the solid line is the best theoretical fit (see text).

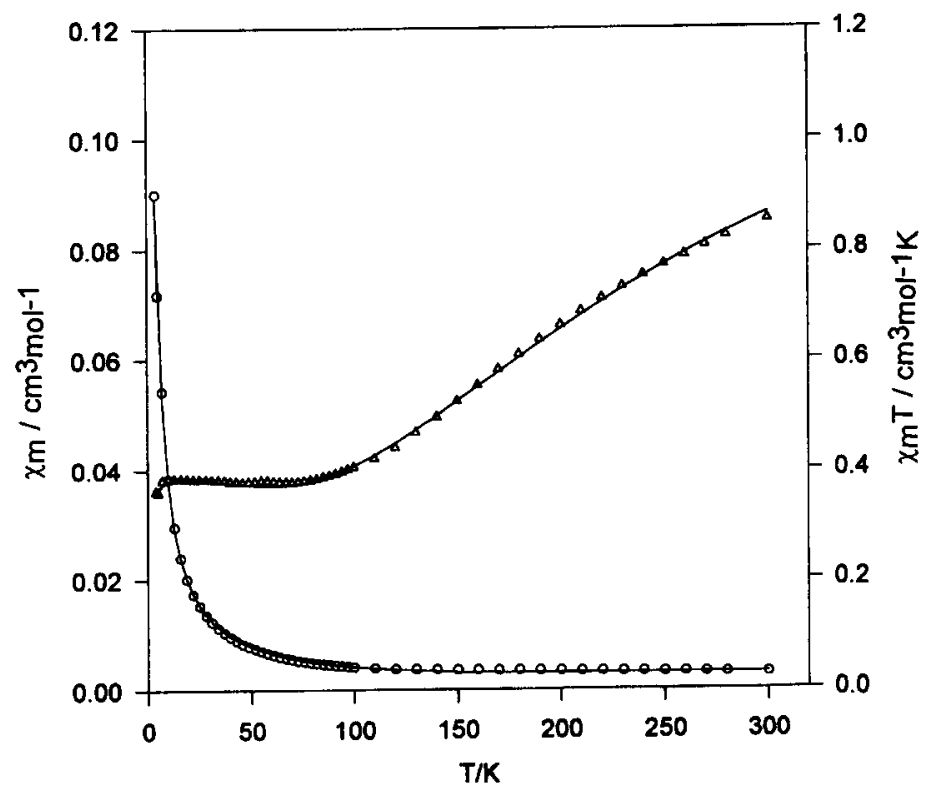

Fig. 4. Thermal variation of the molar magnetic susceptibility for 2 in the form $\chi_{\mathrm{m}}$ and $\chi_{\mathrm{m}} T$ vs $T$.

Finally, it is of interest to note that to our knowledge, compound 2 is the first example of a polymeric copper(II) compound built from a discrete copper(II) carboxylate dimer, carboxylato-bridged polymic chain, and the six-coordinated sodium cation.

\section{SUPPLEMENTARY MATERIAL}

Tables containing atom positions, anisotropic displacement parameters, hydrogen atom location, and bond lengths and angles have been deposited and are also available from the authors on request.

Acknowledgement-This work was supported by a grant of National Science of Council of Taiwan (NSC86-2113-M032005).

\section{REFERENCES}

1. Doedens, R. J., Prog. Inorg. Chem., 1976, 21, 209. 
2. Mehrotra, C. and Bohra, R. C., Metal Carboxylates, Academic Press, New York, 1983.

3. Melnik, M., Coord. Chem. Rev., 1982, 42, 259.

4. Kato, M., Y and Muto, Y., Coord. Chem. Rev., $1988,92,45$

5. Chiari, B., Piovesana, O., Tarantelli and Zanazzi, P. F., Inorg. Chem., 1993, 32, 4834.

6. Bürger, K. S., Chaudhuri, P. and Wieghardt, K., Inorg. Chem., 1996, 35, 2704.

7. Ueyama, N., Yamada, Y., Takeda, J., Okamura, T. and Mori, W., Chem. Commun., 1996, 1377.

8. Simonov, Y. and Malinoskii, T. I., Sov. Phys. Crystallogr., 1970, 15, 310.

9. Martin, R. L. and Waterman, H., J. Chem. Soc., 1957, 2545.
10. Gate, E. J., Le-Page, Y., Cherland, J. P., Lee, F. L. and White, P. S., J. Appl. Cryst., 1989, 22, 384.

11. Carlin, R. L., Magnetochemistry, SpringerVerlag, Berlin, 1986.

12. Mester de, P., Fletcher, S. R. and Skapsky, A. C., J. Chem. Soc., Dalton Trans., 1973, 2575.

13. Hatifield, W. E., J. Appl. Phys., 1981, 52, 1985.

14. Hall, J. W., Marsh, W. E., Weller, R. R. and Hatifield, W. E., Inorg. Chem., 1981, 20, 1033.

15. Bleaney, B., and Bowers, K. D., Proc. R. Soc. London, 1952, A214, 451.

16. Kahn, O., Molecular Magnetism, VCH, New York, 1993, p. 26. 